\title{
Lyme Bay marine protected area: a governance analysis
}

\begin{abstract}
The Marine Protected Area Governance (MPAG) framework can be used to analyse MPA governance by moving away from conceptual discussions to focus on particular governance approaches leading to effectiveness. The framework was applied to the Lyme Bay MPA, southwest England, the site of a controversial fisheries closure, which has subsequently been proposed as a Special Area of Conservation (SAC), as well the location for an NGO-led project focusing on stakeholder engagement. This paper examines a broad range of perspectives on the governance of this MPA, via semi-structured interviews with representatives of different interest groups and document analyses. The MPAG framework found a governance structure with a diversity of incentives, providing for bottom-up stakeholder engagement and awareness-raising coupled with strong top-down legislative structures. Although the fisheries closure and subsequent SAC restrictions have provided the main mechanisms for protecting biodiversity, an NGO-led project has provided a complement to the legislative framework and helped to facilitate a mechanism for adaptive co-management. However, the site is predicted to be subject to external pressures from changes in legislation, state resource restrictions and reduced NGO involvement, which will test the resilience of the structure and whether such a diversity of incentives provides sufficient resilience to maintain MPA effectiveness in the face of these pressures.
\end{abstract}

Rebecca Singer* and Peter JS Jones

Rebecca.Singer.15@alumni.ucl.ac.uk

P.J.Jones@ucl.ac.uk

Department of Geography, University College London, Pearson Building, Gower Street, London WC1E 6BT, UK

*Corresponding author

Highlights:

- Strong legislation to ban bottom-towed gear is supporting observed reef recovery

- An NGO-led working group has facilitated compliance with the legislation

- Effectiveness may be impacted by legislative change or NGO exit

Keywords:

Lyme Bay

Marine protected areas

Governance

This is the authors' version of the final accepted Marine Policy manuscript. Elsevier( $)$ 2018. This manuscript version is made available under the CC-BY-NC-ND 4.0 license.

DOI:10.1016/j.marpol.2018.07.004

\section{(c) creative}

Singer R \& Jones PJS (in press) Lyme Bay Marine Protected Area: a governance analysis. Marine Policy, in press https://doi.org/10.1016/j.marpol.2018.07.004. This manuscript version is made available under the CC-BY-NCND 4.0 license 


\section{Introduction}

Lyme Bay is situated in the English Channel in South West England, and has been identified as a "marine biodiversity hotspot", possessing particularly high species richness, making it one of England's top five most important areas for marine biodiversity [1], [2]. The area possesses reefs which support species such as the pink sea fan (Eunicella verrucosa) and ross coral (Pentapora fascialis), and are therefore of national and international conservation importance. Lyme Bay is also an important area for the provision of social and economic benefits; fishing is an important employer in SW England, contributing 12\% of GVA [3]. Sea angling and dive charters also contribute significantly to the local economy [2]. However, concerns were raised for many years over the effects of mobile demersal fishing, such as scallop dredging, which was damaging the fragile reef habitat.

Lyme Bay was the subject of controversy in 2008 when it was subject to a Statutory Instrument (SI) banning bottom-towed fishing gear from a $206 \mathrm{~km} 2$ area, creating a de facto Marine Protected Area (MPA), the largest UK MPA at the time of its designation [2], [4]. Since 2001, there had been voluntary closures protecting two areas of reef habitat from demersal trawling, but concerns around infringements of these agreements eventually led to a public consultation process by the Department for Food and Rural Affairs (DEFRA) for England, seeking opinions on the implementation of various sizes of closure [2], [5]. The subsequent closure led to widespread academic interest, due to the conflicting interests of stakeholder groups and the significant flaws identified in the stakeholder consultation process [2], [5]. The process led to an erosion of social capital, with a breakdown in trust between some members of the fishing community, Natural England and NGOs involved in the campaign (such as the Devon Wildlife Trust) [2]. Since the closure, a larger area of the Lyme Bay site subsequently came under European Commission (EC) designation though the Habitats Directive in 2010 as part of the Lyme Bay and Torbay candidate Special Area of Conservation (cSAC, also known as a Site of Community Importance (SCI)). Lyme Bay has therefore attracted considerable attention, both as a case study of the conflicting interests of stakeholders, and as a test site for UK and European marine conservation policy [2], [6], [7].

Against this backdrop of strong legislative control and stakeholder conflict, the site has received further attention due to the work of an NGO-led stakeholder group, the Lyme Bay Fisheries and Conservation Reserve (LBFCR) Working Group. This group, created and chaired by the Blue Marine Foundation (BMF), consists of a broad range of stakeholders, and has been publicised as achieving the first example of self-regulation of the fishing community in the UK, through a voluntary agreement [8]. Lyme Bay is therefore an important case study for exploring the relatively understudied roles of both NGOs and voluntary agreements in MPA governance, especially in the current climate of deregulation, uncertainties concerning the role of European legislation after the UK's proposed exit from the European Union (Brexit) and emphasis in governance on stakeholder engagement.

This paper is based on the author's M.Sc. thesis, undertaken as a case study using the Marine Protected Area Governance framework [9], [10]. For methods and comparisons to other case studies, please see the accompanying discussion paper [11].

\section{Context}

Lyme Bay is situated in the English Channel in South West England, sharing its coast between Devon and Dorset. The MPA consists of two overlapping conservation designations; $206 \mathrm{~km} 2$ was designated under the 2008 SI banning bottom-towed gear, and an overlapping area of $275 \mathrm{~km} 2$ was proposed as part of the Lyme Bay and Torbay cSAC in 2010 [12]. The area analysed by this report will be the combination of the SI closure and the Lyme Bay portion of the Lyme Bay and Torbay SCI, along with the LBFCR, collectively referred to here as the Lyme Bay Marine Protected Area (MPA) (Fig. 1). There are a number of adjacent designations to the east of the MPA, including the Chesil and the Fleet SAC, proposed in 1996, and Chesil Beach and Stennis Ledges MCZ, designated in 2013 [13]. 


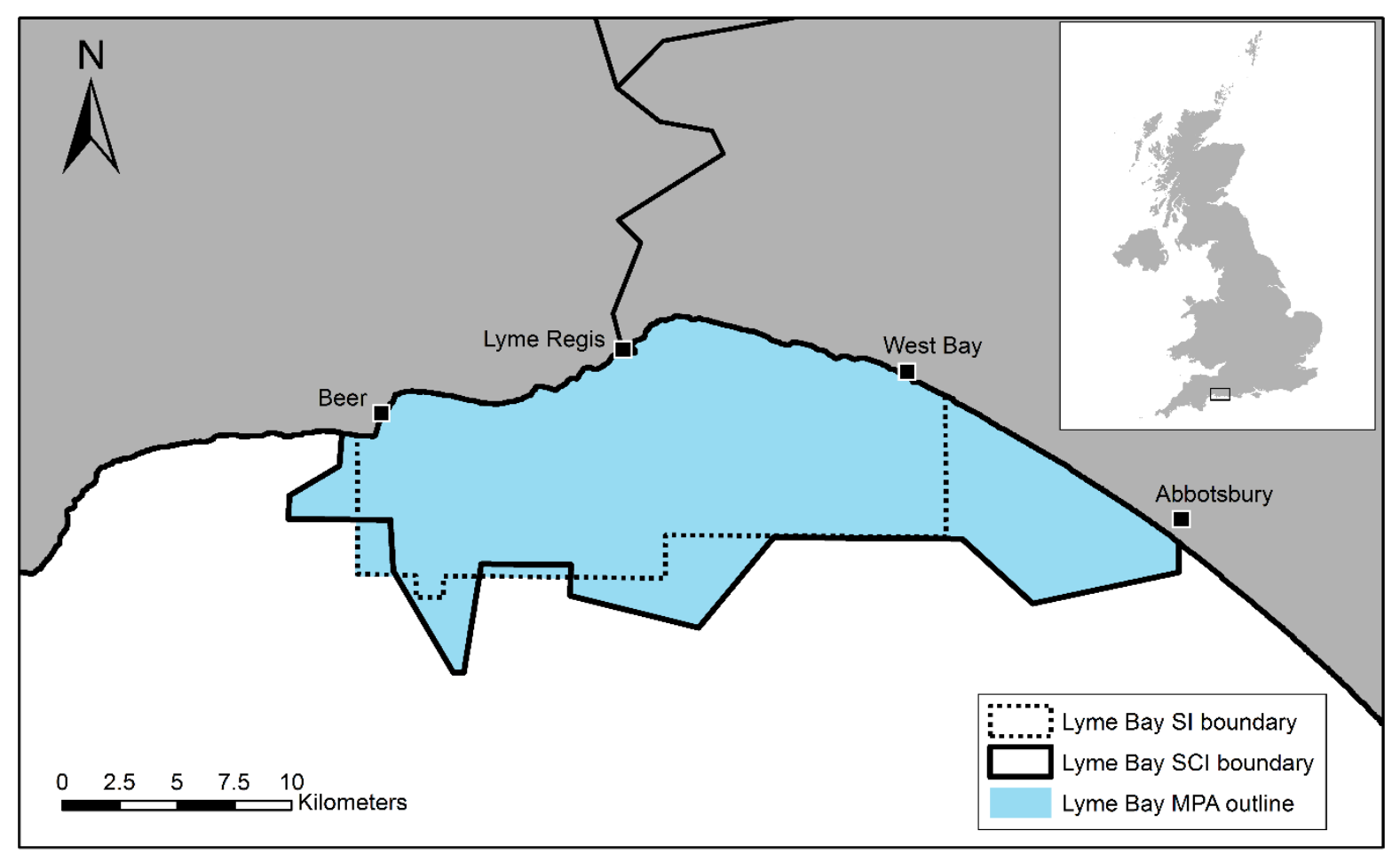

Fig. 1. Designations at Lyme Bay comprising the Lyme Bay MPA discussed in this research [16].

The Jurassic Coast is one of the most popular tourist destinations in Britain. It forms part of the East Devon and Dorset Areas of Outstanding Natural Beauty, and is designated as a World Heritage Site due to its geological and geomorphological features. The tourist economy is an important income generator in SW England, and contributes to the region's low unemployment rate of $4 \%$ (lower than the national average of 4.9\%) (Table 1) [3]. There are a number of coastal fishing towns adjacent to Lyme Bay, and sea angling clubs and dive charters also contribute significantly to these local economies [2].

\begin{tabular}{|l|l|l|l|}
\hline GDP Per Capita & $\begin{array}{l}\text { US } \$ 39,899(2016, \\
23 / 225)\end{array}$ & State Capacity & $1.42(87.3 \%, 2016)$ \\
\hline $\begin{array}{l}\text { GDP Growth } \\
\text { Rate }\end{array}$ & $1.8 \%(2016)$ & $\begin{array}{l}\text { Human Development Index } \\
\text { (HDI) }\end{array}$ & $\begin{array}{l}0.909(16 / 188, \\
2016)\end{array}$ \\
\hline
\end{tabular}

Table 1. Main development metrics and ranks where appropriate for the United Kingdom [14], [15].

\section{Objectives}

\subsection{Conservation objectives}

The Statutory Instrument (SI) by which the MPA was originally designated aims to 'prohibit the use of certain damaging fishing practices that have a negative impact on important biodiversity in Lyme Bay' [17]. These fishing practices consist of the use of mobile gear, in particular scallop dredging, which was breaking up the fragile reef habitat and removing sessile fauna [7]. Although the statutory closure pre-dated the UK Marine and Coastal Access Act 2009, the decision reflected awareness of the act's content and the change in direction for marine conservation [2]. The closure therefore represented a significant attempt by the government to implement an MPA to protect marine life [6], and resulted in the exclusion of mobile gear from a large area encompassing both reef features and interstitial areas. Due to the discovery of extended Annex I reef habitat lying outside of the boundary site of the SI, and therefore requiring protection, the Lyme Bay area was put forward as a candidate SAC in 2010 [18]. The reefs cover approximately $40 \mathrm{~nm} 2$ of the total $90 \mathrm{~nm} 2$ Lyme Bay and Torbay candidate SAC [12]. The site has the legally binding conservation obligations of an SAC, and is 
only awaiting final designation as an SAC by the UK government once the EC have adopted it [1]. Therefore, the second conservation objective of the site is to maintain the reef features of the SAC in 'favourable condition' under the EC Habitats Directive.

\subsection{Operational objectives}

Operational objectives have been set by the Lyme Bay working group, including emphasising socio-economic and cultural benefit of the fisheries, and promoting best possible fishery management practices. These reflect the group's aim for the site to be managed as a multi-use marine reserve 'that will benefit fishermen and conservationists alike' [19]. It should be noted that although through this working group the site has been termed the Lyme Bay Fisheries \& Conservation Reserve, this does not reflect a no-take marine reserve (as the term is often used in the literature) as fishing activities still take place within the area.

\section{Drivers and conflicts}

Fisheries activities permitted within the Lyme Bay MPA include the use of static gear such as potting and netting, scallop diving, and use of mobile demersal gear, with dredging for scallops in restricted areas only. Landings have historically varied due to complex interactions between market drivers, fishing quota (as scallops are not subject to quota so targeted when quota for other stocks used up) and legislation. The increase in market price of scallops (Pecten maximum), coupled with quota pressures on other stocks, caused consistent increases in dredging activity that prompted the initial closure [20]. As a reef associated species, scallops have recovered within the MPA since the closure [7], and observations of increased catch and quality of hand-dived scallops have contributed to the small number of new entrants to the scallop diving industry at Lyme Bay. However, these beneficial conditions for hand-divers further incentivise attempts to remove the closure by mobile fishermen, and increase resentment over equity and 'ownership' of the area.

Although mobile gear is now banned from the majority of the MPA, comprehensive static activity still occurs, and increased market value of whelks for export has added pressure to the fishery. Both mobile and static fishermen have moved over to shellfish in the wake of the dredging ban, particularly whelks (Buccinum undatum) using 'pots', with the majority of effort at the western edge of the MPA by both local boats and larger vessels from ports such as Brixham. The increased safety of static gear inside the closed area has contributed to the increase in whelk fishing effort, but even outside of the MPA, the low cost of whelk gear and bait has allowed significant increases in effort despite gear conflicts with towed trawls. Although the majority of the whelk fishing activity occurs outside of the MPA, activity is reported to be up to thousands of pots, and ecosystem impacts are difficult to discern, with a lack of data on the impacts of potting and netting on temperate reef habitats.

Technological creep has historically allowed increased effort and catch, particularly in dredging boats, which have increased in size and power in recent years. Quota reductions and DEFRA's recent revocation of some licenses has also impacted fishing activity, reducing the diversity of fishing and increasing pressure on nonquota stocks. Finally, storms in the winter of 2013/14 caused significant reef damage, and exacerbated conflicts via perceptions of the levels of storm damage to reef features being comparable to, if not exceeding, the impacts of bottom-towed gear [21].

\section{Governance framework/approach}

The Lyme Bay MPA can be categorised as 'government-led' using the MPAG framework, as it is governed primarily by the state under a clear legal framework [10]. State governance consists of the Statutory Instrument (SI) and the management of inshore fisheries activities by the two local Inshore Fisheries and Conservation Authorities (IFCAs): Southern and Devon \& Severn. As the IFCAs and MMO were formally set up in 2011, their roles at Lyme Bay have developed in parallel and in response to other changes in governance such as the SAC proposal and the BMF working group. Decentralisation allows IFCA judgement on how best to achieve the Habitats Directive objectives under the more precautionary revised approach to fisheries management in marine SACs, with advice from the statutory conservation agency, Natural England [22]. The objectives require a feature-led approach that the IFCAs implement via a range of risk-based byelaws and permitting byelaws. This 
is in contrast to the SI which created a blanket ban on mobile gear in the SI area, in order to achieve the objectives that have since been formalised through the SCI designation.

This varied site management is reflected in the different emphasis on byelaws and permitting byelaws by the two IFCAs. Although the approaches to management differ, both organisations created the 2014 dredging byelaws that prevent the use of bottom-towed gear in sensitive areas of the MPA, consisting of reef areas and buffer zones. Mobile gear is technically allowed in the remaining small corridors of the SCI, but only with a working satellite or smart phone inshore Vessel Monitoring System (iVMS), through a permitting byelaw. Cross-working between IFCAs and MMO, and additional input by the Navy and Border Force, has allowed a relatively strong enforcement presence at Lyme Bay. However, at the time of research, consultations were in progress with a view to removing the Statutory Instrument, and therefore the general ban on mobile gear. It is currently unclear exactly how this would impact the pattern of prohibited fishing areas (Fig. 2), although it would certainly increase reliance on the IFCA byelaw framework for achievement of the SAC objectives, and increase pressure to re-open the site to mobile gear, particularly in the interstitial areas around the reefs, subject to the iVMS requirement and the revised approach. Whilst there used to be official enthusiasm for Lyme Bay as a 'flagship' site within DEFRA, it appeared during research that this enthusiasm had diminished, with the SI now seen as too 'heavy-handed' and top-down. Instead, with ever-deepening budget cuts to bodies such at Natural England, and an increased emphasis on stakeholder partnerships, many interviewees felt that stakeholder committees such as the Lyme Bay working group would be given increased prominence in future MPA governance and related decisions.

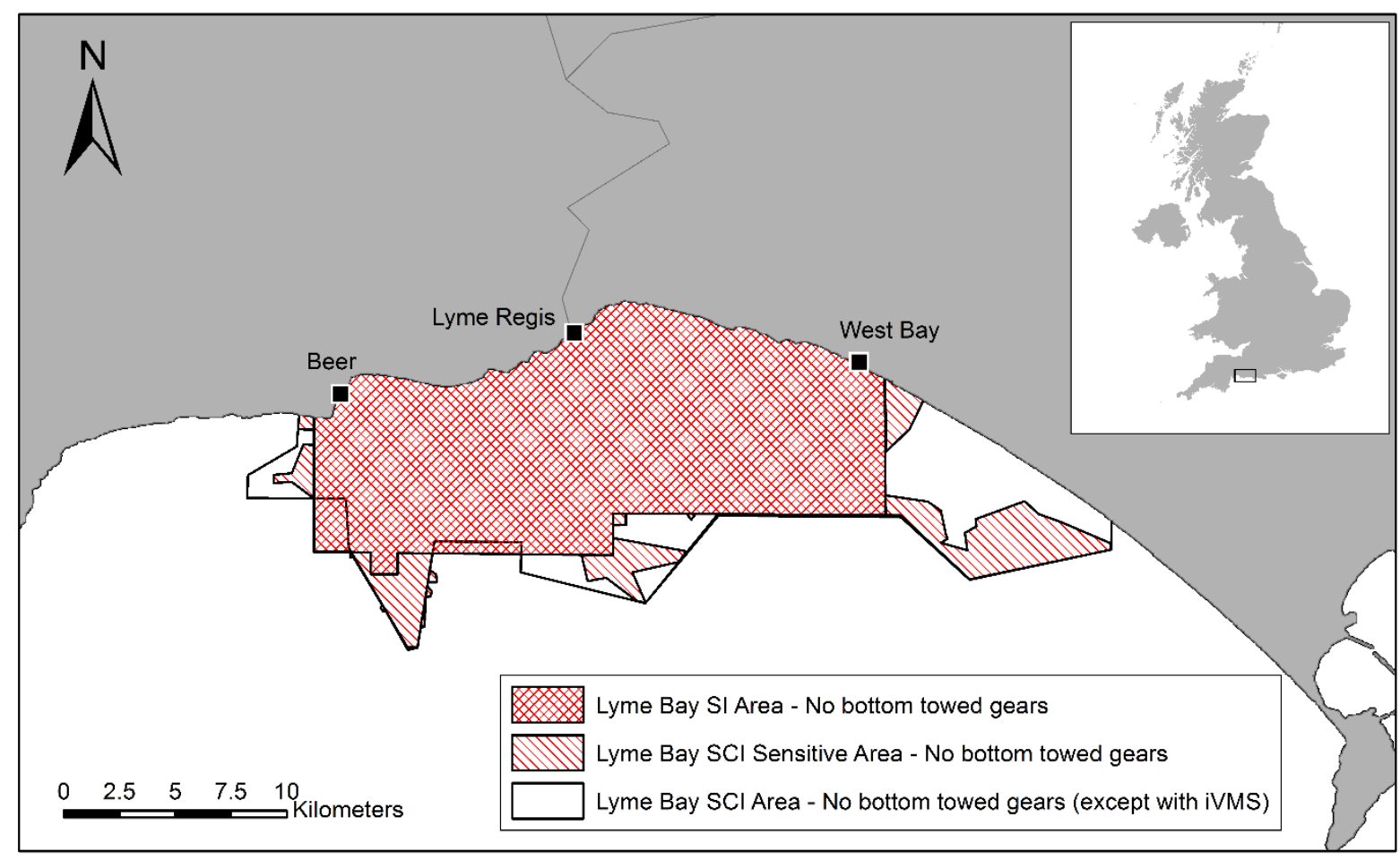

Fig. 2. Lyme Bay prohibited fishing areas [23].

The project by the Blue Marine Foundation at Lyme Bay commenced in 2011 in response to concerns around lack of management and an 'explosion' in static gear following the closure. The resultant Lyme Bay Fisheries and Conservation Reserve Working Group ('the working group') consists of the BMF, fishermen, other MPA users, scientists, IFCAs, MMO, Natural England, private sector and any other interested stakeholders. The working group provides an opportunity to discuss management issues of the Lyme Bay MPA, with the BMF as an independent chair. The fishermen in the group are predominantly local static inshore boats and scallop divers, with no involvement of purely mobile fishermen or incoming users, despite attempts to engage these stakeholders. Under BMF guidance, the working group has instigated a number of initiatives, including introduction of a Lyme Bay Reserve Seafood brand, installation of chiller units and ice machines into two of the local ports to better preserve and add value to the caught shellfish, installation of iVMS to local boats, a schools outreach programme and other awareness raising activities, and facilitation of a number of scientific studies.

Singer R \& Jones PJS (in press) Lyme Bay Marine Protected Area: a governance analysis. Marine Policy, in press https://doi.org/10.1016/j.marpol.2018.07.004. This manuscript version is made available under the CC-BY-NCND 4.0 license 
Voluntary codes of conduct have been developed for fishermen and anglers, along with a memorandum of understanding signed by wider working group members. The voluntary agreement for fishermen has been signed by 41 boats from the four local ports, and provides a voluntary limit for static fishing effort. The group has no direct legislative power but instead promotes discussion, which may be incorporated into IFCA regulation. However, with the involvement of the BMF to reduce in the near future, steer from a consultative committee or a narrower subset of members is envisaged.

\section{Governance effectiveness}

The MPA is currently judged at around level 3 of the MPAG effectiveness scale, with 'some impacts completely addressed, and some partly addressed'. The strong legislation to ban bottom-towed gear is supporting observed reef recovery, thereby addressing the main objectives of the SI and the SCI. Assessments for this 'red risk' activity conducted by the IFCAs have resulted in the 2014 byelaws that restrict mobile gear from sensitive areas (i.e. reef habitat and surrounding buffers). The comprehensive scientific research in the area provides an excellent baseline for monitoring the impacts of bottom-towed gear on fisheries objectives. However, temperate reef recovery is slow, storms have disrupted monitoring, and there is a lack of comparable data, meaning that the time since the closure has not been sufficient for the results of this test closure on the marine environment, particularly on interstitial recovery, to be seen.

At the time of research (summer 2016), management measures for static gear were due in the near future. There were high levels of whelk pots at the edge of (and outside of) the MPA, but little evidence of the impacts of this gear on the MPA features. It was reported that there has been an 'explosion' in static gear since the closure, but different stakeholders gave varied reports, and the lack of consistent data makes it difficult to scientifically justify such statements. However, although there are still large numbers of whelk pots within the western boundary of the MPA, these are below the amount specified in the voluntary code, as fishers did not wish this code to be too restrictive on their activities. The potting levels outlined in the voluntary agreement form a generally accepted marker of upper tolerance by the IFCAs, and increases above this level may trigger a review and potential implementation of restrictions. At the time of research, it was tentatively predicted that no further management measures would be required for static gear as the number of pots was unlikely to exceed the voluntary agreement.

In addition to the direct impacts of fishing activity, there have been instances of reef organisms being damaged by static fishing gear cast adrift during bad weather as well as damaged by discarded 'ghost' fishing gear, such as 'sea fangles' [24]. This is occurring across the SW England coast, damaging reefs and pink sea fans (features of conservation importance found in Lyme Bay).

\section{Incentives}

At Lyme Bay, the strong legal incentives provide the primary mechanism through which SAC objectives are achieved through protection of the reef features (Table 2). However, other categories of incentive help underpin compliance with these regulations, allowing stakeholder input through collaborative learning, increased awareness leading to peer enforcement, and increased social capital and related linkages. Opinion was varied on the resilience of these incentives in the face of potential reduced NGO involvement, reduced funding and reduced legislation.

\section{Economic}

\begin{tabular}{|l|l|l|}
\hline Incentive type & Used & How/Why \\
\hline $\begin{array}{l}\text { Promoting profitable and } \\
\text { sustainable fishing etc. }\end{array}$ & $\mathrm{Y}$ & $\begin{array}{l}\text { The working group encourages fishing at sustainable levels using } \\
\text { voluntary codes of conduct for static fishing and angling. IFCA byelaws } \\
\text { include size limits. There are concerns over the lack of potential for } \\
\text { spillover benefits for the scallop fishery, due to some of the areas of } \\
\text { ground adjacent to the closure not being suitable for scallops. }\end{array}$ \\
\hline $\begin{array}{l}\text { Promoting green } \\
\text { marketing }\end{array}$ & $\mathrm{Y}$ & $\begin{array}{l}\text { The 'Lyme Bay Reserve Seafood' brand can be used by boats signed up } \\
\text { to the voluntary code of conduct, using iVMS surveillance technology } \\
\text { (originally trialled in Lyme Bay), and approved by the Responsible }\end{array}$ \\
\hline
\end{tabular}

Singer R \& Jones PJS (in press) Lyme Bay Marine Protected Area: a governance analysis. Marine Policy, in press https://doi.org/10.1016/j.marpol.2018.07.004. This manuscript version is made available under the CC-BY-NCND 4.0 license 


\begin{tabular}{|l|l|l|}
\hline & & $\begin{array}{l}\text { Fishing Scheme (RFS). Profit increases vary, and no fishermen } \\
\text { explicitly volunteered that increased prices caused them to reduce their } \\
\text { catch; the scheme instead increases buy-in to and support for the } \\
\text { working group. The ability of scallop dredgers (at other UK sites) to sign } \\
\text { up for the RFS scheme led some fishermen to raise 'greenwashing' } \\
\text { concerns. }\end{array}$ \\
\hline $\begin{array}{l}\text { Promoting diversified } \\
\text { and supplementary } \\
\text { livelihoods }\end{array}$ & $\mathrm{Y}$ & $\begin{array}{l}\text { The dive charter sector is growing as a result of the attraction of the } \\
\text { recovering reefs but this is not being promoted as an alternative } \\
\text { livelihood. BMF have funded the provision of ice machines, chiller } \\
\text { units, cool boxes, etc. to promote the freshness of catches and add value } \\
\text { to the seafood products. }\end{array}$ \\
\hline $\begin{array}{l}\text { Provision of state } \\
\text { funding }\end{array}$ & $\mathrm{Y}^{*}$ & $\begin{array}{l}\text { The MPA has benefitted from a comprehensive combination of state, } \\
\text { private and NGO (particularly Blue Marine Foundation) funding, } \\
\text { facilitating an intensive Lyme Bay project and substantial investment in } \\
\text { infrastructure and research. However, with NGO involvement to reduce } \\
\text { and continued austerity cuts to government agencies, it is clear that the } \\
\text { same level of resource cannot be delivered by already stretched } \\
\text { regulators, against an economic background of state funding restrictions } \\
\text { combined with increased country-wide MPA designation. }\end{array}$ \\
\hline $\begin{array}{l}\text { Provision of NGO, } \\
\text { private Sector and user } \\
\text { fee funding }\end{array}$ & $\mathrm{Y}^{*}$ \\
\hline
\end{tabular}

\section{Communication}

\begin{tabular}{|l|l|l|}
\hline Raising awareness & Y & $\begin{array}{l}\text { Public support was a key factor in the original SI closure, and the working } \\
\text { group has further raised awareness of the MPA and its benefits through } \\
\text { multiple avenues, including schools outreach sessions, distribution of the } \\
\text { voluntary agreement, local and national media coverage, a website and } \\
\text { social media presence, and an interactive exhibit at the local Seaton Jurassic } \\
\text { Centre. These initiatives help instil a sense of pride in sustainable fishing } \\
\text { for the local static boats, although a narrative of the benefits of reduced } \\
\text { catches was not explicitly supported by the fishermen interviewed. A video } \\
\text { graphically illustrating the impacts of scallop dredging in Lyme Bay was } \\
\text { very effective in raising public concerns and was one of the factors leading } \\
\text { to the SI that originally created and closed the MPA to demersal trawling. }\end{array}$ \\
\hline $\begin{array}{l}\text { Promoting recognition of } \\
\text { benefits }\end{array}$ & $\mathrm{Y}$ & $\begin{array}{l}\text { The working group emphasises general ecosystem sustainability and widely } \\
\text { promotes the success of conservation measures in the area. }\end{array}$ \\
\hline $\begin{array}{l}\text { Promoting recognition of } \\
\text { regulations and } \\
\text { restrictions }\end{array}$ & $\mathrm{Y}$ & $\begin{array}{l}\text { IFCA regulations are communicated directly to affected users, and the } \\
\text { working group allows a forum for questions and real-time debates between } \\
\text { regulators and the group members, but is limited to the local inshore, static } \\
\text { fishermen that are members of the group. Increased awareness of the MPA } \\
\text { and its regulations has contributed to the dramatic increase in the reports of } \\
\text { infringements, by fishermen, other MPA users and members of the public. }\end{array}$ \\
\hline
\end{tabular}

\section{Knowledge}

\begin{tabular}{|l|l|l|}
\hline $\begin{array}{l}\text { Promoting collective } \\
\text { learning }\end{array}$ & Y & $\begin{array}{l}\text { The working group allows for discussion between scientists, regulators, } \\
\text { fishermen, NGOs, the private sector and wider attendees. Adaptive } \\
\text { management and collective learning is seen in the potting Ph.D. study } \\
\text { where fishermen voluntarily closed small areas, with the aim to inform } \\
\text { management regulations. Concern was expressed that the huge body of } \\
\text { scientific research at the site, including yearly reef monitoring, would be } \\
\text { wiped out by changes to legislation such as the re-opening of the site to } \\
\text { mobile gear. Collective learning could be particularly focused on the } \\
\text { relative importance of interstitial areas in application of SCI objectives to } \\
\text { reefs, with IFCAs moving to formally clarify steer from Natural England } \\
\text { on whether interstitial protection could promote reef regeneration if } \\
\text { protected from demersal trawling in the longer term. }\end{array}$ \\
\hline $\begin{array}{l}\text { Agreeing approaches for } \\
\text { addressing uncertainty }\end{array}$ & Y & $\begin{array}{l}\text { Whilst taking a precautionary approach is a requirement of EC legislation, } \\
\text { including the Habitats Directive, there is no specific approach for } \\
\text { implementing this principle in the MPA/SCI, though the original SI could } \\
\text { be considered precautionary and the revised approach to restricting fishing } \\
\text { in SCIs through a proactive risk-based approach also arguably takes a } \\
\text { precautionary approach. }\end{array}$ \\
\hline
\end{tabular}




\begin{tabular}{|l|l|l|}
\hline $\begin{array}{l}\text { Independent advice and } \\
\text { arbitration }\end{array}$ & $\mathrm{Y}$ & $\begin{array}{l}\text { Research partnerships with marine scientists at the University of Plymouth } \\
\text { to monitor the ecological and economic impacts of the MPA have served } \\
\text { to provide independent advice. }\end{array}$ \\
\hline
\end{tabular}

\section{Legal}

\begin{tabular}{|c|c|c|}
\hline Hierarchical obligations & $\mathrm{Y}$ & $\begin{array}{l}\text { State governance is predominantly steered through obligations under the } \\
\text { EC Habitats Directive, with control over byelaws decentralised to IFCA } \\
\text { fisheries management, allowing tailored adaptive management. However, } \\
\text { the SI and IFCA } 2014 \text { byelaws provide the primary mechanism for } \\
\text { protection of biodiversity by the banning of mobile gear, and the removal } \\
\text { of the SI would increase reliance on byelaws for protection of the site. }\end{array}$ \\
\hline $\begin{array}{l}\text { Capacity for } \\
\text { enforcement }\end{array}$ & $\mathrm{Y}^{*}$ & $\begin{array}{l}\text { Satellite VMS is required on boats over } 12 \mathrm{~m} \text {, but recent iVMS trials } \\
\text { using smart phone technology have had mixed success. Working iVMS } \\
\text { units are seen as a key factor for future regulation, particularly if the site } \\
\text { were to be re-opened to mobile gear. Data from the iVMS units informs } \\
\text { management by the IFCAs, but a lack of previous data for inshore boats } \\
\text { makes identifying trends difficult. Unregistered boats without iVMS may } \\
\text { also be fishing and selling catch. However, cross-working between IFCAs } \\
\text { and MMO, and additional input by the Navy and Border Force, has } \\
\text { allowed a relatively strong presence at Lyme Bay, coupled with strong } \\
\text { peer enforcement. }\end{array}$ \\
\hline Penalties for deterrence & $\mathrm{Y}$ & $\begin{array}{l}\text { Although prosecutions remain difficult, successful joint IFCA/MMO } \\
\text { prosecutions of an illegal scallop dredger in } 2015 \text { and } 2016 \text { provides a } \\
\text { clear deterrent to other boats. }\end{array}$ \\
\hline $\begin{array}{l}\text { Protection from } \\
\text { incoming users }\end{array}$ & $\mathrm{Y}$ & $\begin{array}{l}\text { Infringements have decreased hugely since the original closure, and now } \\
\text { consist of sporadic breaking of the mobile gear regulations by incoming } \\
\text { boats from larger ports such as Brixham, though these can lead to major } \\
\text { impacts. Tough penalties are particularly important for these visiting } \\
\text { boats which are less able to access the local or working group incentives. }\end{array}$ \\
\hline $\begin{array}{l}\text { Attaching conditions to } \\
\text { use and property rights }\end{array}$ & $\mathrm{Y}$ & $\begin{array}{l}\text { One of the conditions of the licence to fish is adherence to the MPA/SCI } \\
\text { restrictions. }\end{array}$ \\
\hline $\begin{array}{l}\text { Cross-jurisdictional } \\
\text { coordination }\end{array}$ & $\mathrm{Y}^{*}$ & $\begin{array}{l}\text { Regulatory methods differ between the two IFCAs, with different } \\
\text { emphasis on traditional byelaws vs. permitting byelaws, in part due to the } \\
\text { separate challenges and histories of the two different jurisdictions - the } \\
\text { proposed joint IFCA management plan should aid coordination but this } \\
\text { remains to be seen, with one IFCA particularly interested in re-opening } \\
\text { the SCI to dredging through the lifting of the blanket ban and the other } \\
\text { more interested in maintaining the blanket ban. }\end{array}$ \\
\hline $\begin{array}{l}\text { Clear and consistent } \\
\text { legal definitions }\end{array}$ & $\mathrm{Y}^{*}$ & $\begin{array}{l}\text { The inherent difficulties in two IFCAs managing the site increases the } \\
\text { need for a consistent coherent legal direction for conservation, with clear } \\
\text { steer from Natural England, MMO and DEFRA. }\end{array}$ \\
\hline $\begin{array}{l}\text { Legal adjudication } \\
\text { platforms }\end{array}$ & $\mathrm{Y}$ & Prosecuted fishermen have the right of appeal. \\
\hline $\begin{array}{l}\text { Transparency and } \\
\text { fairness }\end{array}$ & $\mathrm{Y}$ & $\begin{array}{l}\text { MMO and IFCAs operate transparently, with a wide range of information } \\
\text { publicly available and the IFCA Committees and LBFCR working group } \\
\text { environment further increasing transparency. }\end{array}$ \\
\hline
\end{tabular}

Participation
\begin{tabular}{|l|l|l|}
\hline $\begin{array}{l}\text { Establishing } \\
\text { collaborative platforms }\end{array}$ & $\mathrm{Y}$ & $\begin{array}{l}\text { The working group is cited as a rare example of discussion across } \\
\text { horizontal (between users) and vertical (between regulators and users) } \\
\text { networks. }\end{array}$ \\
\hline Neutral facilitation & $\mathrm{Y}^{*}$ & $\begin{array}{l}\text { Neutral facilitation by an external body (BMF) has been crucial for the } \\
\text { development of the working group. However, IFCA representatives have } \\
\text { been proposed as the leaders of the working group as the BMF's } \\
\text { involvement reduces, which may undermine this incentive. }\end{array}$ \\
\hline $\begin{array}{l}\text { Decentralising } \\
\text { responsibilities }\end{array}$ & $\mathrm{Y}$ & $\begin{array}{l}\text { Most regulatory responsibilities are decentralised to the two local IFCAs } \\
\text { and some responsibilities have been taken on by the working group. }\end{array}$ \\
\hline $\begin{array}{l}\text { Peer enforcement } \\
\text { Y }\end{array}$ & $\begin{array}{l}\text { Peer enforcement has greatly increased with infringements now reported } \\
\text { by fishermen, anglers and members of the public, and it was a local }\end{array}$ \\
\hline
\end{tabular}

Singer R \& Jones PJS (in press) Lyme Bay Marine Protected Area: a governance analysis. Marine Policy, in press https://doi.org/10.1016/j.marpol.2018.07.004. This manuscript version is made available under the CC-BY-NCND 4.0 license 


\begin{tabular}{|l|l|l|}
\hline & & $\begin{array}{l}\text { fishermen who reported the visiting illegal scallop dredger who was } \\
\text { prosecuted. }\end{array}$ \\
\hline $\begin{array}{l}\text { Building trust and the } \\
\text { capacity for cooperation }\end{array}$ & $\mathrm{Y}^{*}$ & $\begin{array}{l}\text { Social capital has greatly increased through the working group, against a } \\
\text { history of stakeholder tensions. A voluntary cap on static gear effort was } \\
\text { set above the level that boats were fishing; the agreement therefore does } \\
\text { not directly reduce effort, and instead could be considered a symbolic } \\
\text { gesture that aims to change mindsets. However, this capital is limited } \\
\text { predominantly to local static gear fishermen, as mobile fishermen see } \\
\text { little incentive to attend, and incoming users are hard to reach through } \\
\text { such a format. Incoming whelk boats therefore continue to fish well } \\
\text { above the suggested levels at the western end of the MPA. }\end{array}$ \\
\hline $\begin{array}{l}\text { Building linkages } \\
\text { between relevant } \\
\text { authorities and user } \\
\text { representatives }\end{array}$ & $\mathrm{Y}$ & $\begin{array}{l}\text { The working group has developed relationships between representatives } \\
\text { of the agencies and user groups, but is again limited to local static gear } \\
\text { fishermen. }\end{array}$ \\
\hline $\begin{array}{l}\text { Potential to influence } \\
\text { higher institutional levels }\end{array}$ & $\mathrm{Y}$ & $\begin{array}{l}\text { The working group has increased the perceived 'voice' and influence of } \\
\text { MPA users on higher institutional levels in DEFRA. }\end{array}$ \\
\hline
\end{tabular}

The Lyme Bay Reserve seafood brand was divisive across fishermen, with opinions ranging from strong support for the scheme, to concerns that partially focused on the 'greenwashing' Responsible Fishing Scheme. However, the Lyme Bay Reserve seafood brand, and other economic incentives such as funding and facilities, encourage buy-in to the working group and MPA, thereby facilitating participation and collective learning incentives, as well as peer enforcement. At a site with a historical breakdown of social capital through tension and conflict, relationships have moved in a hugely positive direction. Many stakeholders therefore cited 'maintained high capacity for enforcement' as the only possible improvement to the MPA. However, the increased social capital could be impacted by any change to the legislation such as SI removal. The numerous scientific studies taking place in Lyme Bay, as well as providing an ecological baseline for the site, have increased views of legitimacy in the regulatory process in the eyes of fishermen. Re-allowing scallop dredgers to the area has the potential to impact the informed management of the site, as well as the relationships between fishermen and regulators, which have benefited greatly from the working group.

\section{Cross cutting themes}

\subsection{Equity issues}

There is some resentment of the inclusion of part-time fishermen in the working group, as they are perceived to deserve less of a 'stake' in management of the MPA. Mobile fishermen who have already been excluded from the MPA further resent the large amount of static gear outside of the MPA area, as well as the perceived bias towards static gear, both in terms of the working group emphasis and the national drive to designate MPAs, which are seen as closing huge areas of the coast to mobile gear. Equitable treatment of all stakeholders is cited as a key argument by regulators for re-permitting mobile gear access around the reef areas, but must be carefully balanced with effectiveness of the MPA [25], which is currently high due to the exclusion of mobile gear. With the IFCA role requiring balancing stakeholders' interests as well as managing fisheries for conservation, this can present conflicts in the achievement of objectives [22].

\subsection{Role of $\mathrm{NGOs}$}

The role of NGOs within the working group has been largely limited to the role of the BMF, with a low NGO presence as a deliberate choice to ensure maximum participation of fishermen after historic conflicts. Originally the BMF were viewed as being 'just another group' who wanted to ban fishing, in the context of past tensions, and have successfully overcome this label in order to engage with fishermen. Any accusations of imposition predominantly come from excluded mobile gear fishermen who already felt that the original closure was imposed on them, but also from some static fishermen, who are wary of the working group and its initiatives. 


\subsection{Role of leadership}

With the BMF's involvement reducing, the working group may end if there is no leadership influence going forward, and this was a key concern of research participants. The suggested format is a smaller working group with IFCA leadership and MMO support, although BMF presence at the site will initially be reduced rather than removed to ensure continuation of the project. Leadership will be crucial for coordinating funding through iVMS data and ensuring that compliance is maintained, but IFCAs may struggle to deliver a working group on their resources, and prioritise other commitments. Leadership of the group by a regulator may undermine neutrality and reduce the current support for and cooperation with the legislation, and use of an independent chair should be considered.

\subsection{Role of science}

The Lyme Bay site has raised discussion around the nature of site integrity in achievement of conservation objectives, as the feature-led SAC designation contrasts with the site-led conservation created by the SI [18]. Seabed areas not previously considered as reef can exhibit regeneration, with recent studies showing that interstitial areas previously identified as soft sediment can support reef species if they are left undisturbed by demersal trawling [7], [21]. Interactions between reef and non-reef ecosystem elements further require that the site be considered as an integral whole for ecological and legal purposes [18].

Potential SI removal will create pressure for the site to be re-opened around Annex 1 reef features, especially with one IFCA already planning to submit an application to Natural England to allow dredging in between the reef features, in order to formally clarify the conservation guidance. It is suggested that any re-opening of the site should be stepwise and involve careful monitoring, but stretched IFCA budgets may mean such monitoring would be less comprehensive than ideally desired [22]. Although many users anecdotally report a huge improvement in the fishery, with catch increases and many new species, some mobile fishermen still dispute the fact that the site is improving, and the slow recovery of temperate reef systems and impacts from storm waves means that scientifically proving reef recovery has been difficult [21]. Further research into interstitial recovery should be conducted to allow adequate legitimate protection under SAC objectives. With use of evidence and the precautionary principle a prominent theme in the designation of MCZs [26], Lyme Bay has the potential to feed into wider arguments and debates.

\subsection{Voluntary agreements}

The use of voluntary agreements at Lyme Bay is an important case study, due to previous limited research on their use in MPAs [27], and increased government emphasis on stakeholder engagement and the use of voluntary agreements. Although the voluntary agreement to set a static gear effort limit (maximum pot numbers per vessel) at Lyme was set above the present and likely future level of static gear effort, and therefore has not directly reduced static effort levels, noted benefits include a mechanism to prevent future increases and change mindsets, a tool to control management practices such as bait use which are difficult to enforce, and a 'stepping stone' to legislation that caps effort. There are contrasting opinions on whether the static gear voluntary agreement should be put into legislation, and one suggestion is that it could be adopted as a permitting scheme which would be relatively flexible. The use of voluntary agreements at Lyme has benefited from the relative homogenisation of the users within the working group and the neutral leadership of the BMF, and should be viewed in the context of the backdrop of strong legislation.

\section{Conclusion}

Analysis of the Lyme Bay MPA through the MPAG framework has identified a complex and unique site. Although a diversity of incentives encourage effectiveness of the MPA, the strong legislation to ban bottomtowed gear has been the most important for reef recovery. However, presence of a neutral NGO at the site has facilitated a significant investment of private and NGO funding, a wide range of awareness raising initiatives, development of social capital and a designated forum for collaborative learning. Although the working group's static catch voluntary agreement has not directly resulted in a reduction in static gear effort, the incentives provided instead help to change mindsets and promote cooperation and compliance with the strong legislative structure. This cooperation and compliance protects the benthic habitats from the effects of mobile gear and provides the primary mechanism for achievement of the SAC objectives, and assessments and management measures for lower risk impacts are expected to be implemented in the near future. Some issues still remain with 
incoming boats, which are difficult to engage through the working group and other local incentives, and should be targeted going forward by improved surveillance and patrols. However, effectiveness is generally high (pending the outcome of further Habitat Risk Assessments) due to the banning of mobile gear and the current low infringement rate.

With effectiveness high, recommendations for Lyme Bay turn to the large number of perturbations to the system expected in the near future. With potential upcoming removal of the statutory instrument by government, pressure to re-allow access by mobile gear around the conservation features of interest will increase. As Lyme Bay is currently a test site for such a closure and providing evidence for reef self-renewal outside of areas designated as Annex 1 reef habitat, it is important that increased monitoring and research is conducted to ensure the SAC objective of protecting reef habitat is adequately defined. Additionally, participative incentives have successfully allowed a format for collaborative learning and enthusiasm for peer enforcement, but with a backdrop of stakeholder conflict and mistrust of NGOs and regulators still within memory, it must be ensured that similar mistakes in stakeholder engagement are not repeated in any further decisions. With potential BMF exit, a general lack of funding and perceived lack of participation in the working group by some IFCA members, this creates a potential gap of leadership, funding and political will to maintain a closed area. A huge amount of investment, both of time and funding, has been invested into Lyme Bay, and changes such as the removal of the statutory instrument have the potential to disrupt the fragile relationships between stakeholders, reduce the scientific value of past monitoring, and disrupt recovery of biodiversity, decreasing effectiveness of a site that could otherwise be a flagship for UK marine conservation. 


\section{References}

[1] JNCC, Lyme Bay and Torbay - SAC selection, (2010). http://jncc.defra.gov.uk/protectedsites/sacselection/sac.asp?EUCode=UK0030372. (accessed May 1, 2018).

[2] D.M. Fleming, P.J.S. Jones, Challenges to achieving greater and fairer stakeholder involvement in marine spatial planning as illustrated by the Lyme Bay scallop dredging closure, Mar. Policy. 36 (2012) 370-377. doi:10.1016/j.marpol.2011.07.006.

[3] ONS, Regional labour market statistics in the UK, (2016) 1-26.

[4] T.F. Stevens, E. V. Sheehan, S.C. Gall, S.C. Fowell, M.J. Attrill, Monitoring benthic biodiversity restoration in Lyme Bay marine protected area: Design, sampling and analysis, Mar. Policy. 45 (2014) 310-317. doi:10.1016/j.marpol.2013.09.006.

[5] C.E. Hattam, S.C. Mangi, S.C. Gall, L.D. Rodwell, Social impacts of a temperate fisheries closure: Understanding stakeholders' views, Mar. Policy. 45 (2014) 269-278. doi:10.1016/j.marpol.2013.09.005.

[6] S.C. Mangi, L.D. Rodwell, C. Hattam, Assessing the impacts of establishing MPAs on fishermen and fish merchants: The case of Lyme Bay, UK, Ambio. 40 (2011) 457-468. doi:10.1007/s13280-0110154-4.

[7] E. V. Sheehan, T.F. Stevens, S.C. Gall, S.L. Cousens, M.J. Attrill, Recovery of a temperate reef assemblage in a marine protected area following the exclusion of towed demersal fishing, PLoS One. 8 (2013) 1-12. doi:10.1371/journal.pone.0083883.

[8] Fishermen agree to limit Lyme Bay catches, Guard. (2012). https://www.theguardian.com/environment/2012/jul/02/fishing-limit-lyme-bay-catches (accessed May 1, 2018).

[9] R. Singer, A governance analysis of Lyme Bay MPA, University College London, 2016.

[10] P. Jones, Governing Marine Protected Areas: Resilience through diversity, 1st ed., Routledge, Oxfordshire UK, New York USA, 2014.

[11] Jones P.J.S. (forthcoming) Case studies in marine protected area governance: introduction and discussion. Marine Policy

[12] Natural England, Lyme Bay and Torbay cSAC (UK0030372), (2012).

http://publications.naturalengland.org.uk/publication/3263526 (accessed May 1, 2018).

[13] Natural England, Chesil Beach and Stennis Ledges MCZ Factsheet (MCZ031), (2013).

http://publications.naturalengland.org.uk/publication/5501887130370048 (accessed May 1, 2018).

[14] The World Bank, Data Bank, (2016). https://data.worldbank.org/ (accessed May 1, 2018).

[15] United Nations Development Programme, Human Development Report, 2016.

[16] S.E. Rees, M. Ashley, L. Evans, S. Mangi, L. Rodwell, M. Attrill, O. Langmead, E. Sheehan, A. Rees, An evaluation framework to determine the impact of the Lyme Bay Fisheries and Conservation Reserve and the activities of the Lyme Bay Consultative Committee on ecosystem services and human wellbeing, 2016.

[17] Defra, Explanatory Memorandum To the Lyme Bay Designated Area (Fishing Restrictions) Order 2008 No.1584, (2008).

Singer R \& Jones PJS (in press) Lyme Bay Marine Protected Area: a governance analysis. Marine Policy, in press https://doi.org/10.1016/j.marpol.2018.07.004. This manuscript version is made available under the CC-BY-NCND 4.0 license 
[18] S.E. Rees, E. V. Sheehan, E.L. Jackson, S.C. Gall, S.L. Cousens, J.-L. Solandt, M. Boyer, M.J. Attrill, A legal and ecological perspective of 'site integrity' to inform policy development and management of Special Areas of Conservation in Europe, Mar. Pollut. Bull. 72 (2013) 14-21. doi:10.1016/j.marpolbul.2013.03.036.

[19] Lyme Bay Fisheries and Conservation Reserve, Website Homepage, (2016). http://www.lymebayreserve.co.uk/ (accessed May 1, 2018).

[20] T. Appleby, Damage by fishing in the UK's Lyme Bay - A problem of regulation or ownership?, J. Water Law. 18 (2007) 39-46.

[21] E. V Sheehan, S.L. Cousens, S.C. Gall, D.R. Bridger, S. Cocks, M.J. Attrill, Lyme Bay - A case study: Response of the benthos to the zoned exclusion of towed demersal fishing gear in Lyme Bay; 5 years after the closure, 2016.

[22] L.D. Rodwell, J. Lowther, C. Hunter, S.C. Mangi, Fisheries co-management in a new era of marine policy in the UK: A preliminary assessment of stakeholder perceptions, Mar. Policy. 45 (2014) 279286. doi:10.1016/j.marpol.2013.09.008.

[23] Marine Management Organisation, Lyme Bay and Torbay Prohibited Fishing Areas, (2011). http://webarchive.nationalarchives.gov.uk/20140305105745/http://www.marinemanagement.org.uk/pro tecting/conservation/documents/lyme_bay/prohibited_sensitive_a.pdf (accessed May 1, 2018).

[24] E. V. Sheehan, A. Rees, D. Bridger, T. Williams, J.M. Hall-Spencer, Strandings of NE Atlantic gorgonians, Biol. Conserv. 209 (2017) 482-487. doi:10.1016/j.biocon.2017.03.020.

[25] B.S. Halpern, C.J. Klein, C.J. Brown, M. Beger, H.S. Grantham, S. Mangubhai, M. Ruckelshaus, V.J. Tulloch, M. Watts, C. White, H.P. Possingham, Achieving the triple bottom line in the face of inherent trade-offs among social equity, economic return, and conservation, Proc. Natl. Acad. Sci. 110 (2013) 6229-6234. doi:10.1073/pnas.1217689110.

[26] E.M. De Santo, Assessing public "participation" in environmental decision-making: Lessons learned from the UK Marine Conservation Zone (MCZ) site selection process, Mar. Policy. 64 (2016) 91-101. doi:10.1016/j.marpol.2015.11.003.

[27] C.K. Whitney, J. Gardner, N.C. Ban, C. Vis, S. Quon, S. Dionne, Imprecise and weakly assessed: Evaluating voluntary measures for management of marine protected areas, Mar. Policy. 69 (2016) 92101. doi:10.1016/j.marpol.2016.04.011. 